\title{
Selection of Bacillus thuringiensis strains in citrus and their pathogenicity to Diaphorina citri (Hemiptera: Liviidae) nymphs
}

\author{
Sílvia de Oliveira Dorta ${ }^{1,2}$ iD , Juliana Balbinotte ${ }^{3}$, Rose Monnerat $^{4}$, João Roberto Spotti Lopes ${ }^{3}$, \\ Tatiane da Cunha ${ }^{1,2}$, Odimar Zanuzo Zanardi ${ }^{5}$, Marcelo Pedreira de Miranda ${ }^{5}$, \\ Marcos Antonio Machado ${ }^{2}$ and Juliana de Freitas-Astúa ${ }^{6,7}$ \\ ${ }^{1}$ Programa de Pós-Graduação em Microbiologia Agrícola, Escola Superior de Agricultura Luiz de Queiroz, Universidade de São \\ Paulo, Piracicaba, SP, Brazil; ${ }^{2}$ Laboratório de Biotecnologia, Centro de Citricultura Sylvio Moreira, Instituto Agronômico de Campinas, \\ Cordeirópolis, SP, Brazil; ${ }^{3}$ Laboratório de Insetos Vetores de Fitopatógenos, Departamento de Entomologia e Acarologia, Escola Supe- \\ rior de Agricultura Luiz de Queiroz, Universidade de São Paulo, Piracicaba, SP, Brazil; ${ }^{4}$ Embrapa Recursos Genéticos e Biotecnologia, \\ Brasília, DF, Brazil; ${ }^{5}$ Fundo de Defesa da Citricultura (Fundecitrus), Araraquara, SP, Brazil; ${ }^{6}$ Embrapa Mandioca e Fruticultura, Cruz das \\ Almas, BA, Brazil and ${ }^{7}$ Laboratório de Bioquímica Fitopatológica, Instituto Biológico, São Paulo, SP, Brazil
}

\begin{abstract}
Bacillus thuringiensis (Bt) toxins are effective in controlling insect pests either through the spraying of products or when expressed in transgenic crops. The discovery of endophytic Bt strains opened new perspectives for studies aimed at the control of sapsucking insects, such as the Asian citrus psyllid Diaphorina citri Kuwayama (Hemiptera: Liviidae), a vector of "Candidatus Liberibacter spp.," associated with citrus huanglongbing (HLB). In this study, translocation of endophytic Bt strains in citrus seedlings inoculated with Bt suspension delivered by soil-drench, and their systemic pathogenicity to $D$. citri nymphs were investigated. The pathogenicity of three wild-type Bt strains against $D$. citri third-instar nymphs was demonstrated. Among the 10 recombinant strains tested (each of them harboring a single cry or cyt gene), 3 can be highlighted, causing $42 \%-77 \%$ and $66 \%-90 \%$ nymphal mortality at 2 and $5 \mathrm{~d}$ after inoculation, respectively. The isolation of Bt cells from young citrus shoots and dead nymphs, and PCR performed with specific primers, confirmed the involvement of the Bt strains in the psyllid mortality. This is the first report showing the translocation of $\mathrm{Bt}$ strains from citrus seedling roots to shoots and their potential to control $D$. citri nymphs that fed on these soil-drench inoculated seedlings. The Bt strains that caused the highest mortality rates have the potential to be used as bioinsecticides to control D. citri and the identified genes can be used for the production of transgenic Bt citrus.
\end{abstract}

Key words Asian citrus psyllid; Citrus sinensis; Cry toxins; endophytic Bt; huanglongbing; young shoots

Correspondence: Juliana de Freitas-Astúa, Embrapa Mandioca e Fruticultura, Embrapa, Av. Embrapa, s/n, Chapadinha, Cruz das Almas, BA, 44380-000, Brazil. Phone: +55 61 3448-4433, Fax: +55 61 3448-4890/3448-4891; Email: juliana. astua@embrapa.br

\section{Introduction}

Asian citrus psyllid, Diaphorina citri Kuwayama (Hemiptera: Liviidae), is a serious threat to citrus production worldwide, since it is a vector of the phloem-limited bacteria "Candidatus Liberibacter asiaticus" and " $\mathrm{Ca}$. L. americanus" associated with huanglongbing (HLB) 
disease (Gottwald, 2010). The five nymphal instars of $D$. citri have little mobility and feed on young citrus shoots, whereas adults exhibit greater mobility, feeding on leaves of all developmental stages and also on stems (Hall et al., 2012). Females lay eggs only in the presence of young shoots (Cifuentes-Arenas et al., 2018), which are nutritionally richer compared to the mature ones (Sétamou et al., 2016). Nymphs and adults can acquire and inoculate the bacteria by feeding on the sap of infected plants (Inoue et al., 2009; Pelz-Stelinski et al., 2010). The preconized HLB management is based on the use of healthy vegetative material produced under protected environment, reducing the source of inoculum by eliminating symptomatic trees from the field, and D. citri chemical control (Belasque Jr. et al., 2010; Bassanezi et al., 2013).

Among D. citri management tactics, the chemical control through spraying and/or application of insecticides via soil-drench or trunk have been widely used by growers to reduce the insect vector population and HLB spread in citrus groves (Grafton-Cardwell et al., 2013; Qureshi et al., 2014; Boina \& Bloomquist, 2015; Miranda et al., 2016). However, the overuse of pesticides can cause mortality of natural enemies and pollinators, favor the occurrence of secondary pest outbreaks, and accelerate the selection process of $D$. citri populations resistant to the main insecticides (Tiwari et al., 2011; Monzo et al., 2014). For this reason, several research groups have been searching for alternatives to control $D$. citri, including RNA interference (El-Shesheny et al., 2013; Galdeano et al., 2017) and biological control with natural enemies such as the ectoparasitoid Tamarixia radiata Waterston (Hymenoptera: Eulophidae) (Parra et al., 2010; Flores \& Ciomperlik, 2017) and entomopathogenic agents (Conceschi et al., 2016; Ausique et al., 2017).

Among the entomopathogens, Bacillus thuringiensis Berliner (Bacillales: Bacillaceae) (Bt) has been widely used in biopesticide formulations containing bacterial spores and crystals (Schnepf et al., 1998; Jouzani et al., 2017). Bt has high activity against immature stages of several pest insects belonging to different orders, such as Lepidoptera, Coleoptera, Diptera (Xu et al., 2014), Hemiptera (Porcar et al., 2009; Torres-Quintero et al., 2016), Hymenoptera, and Orthoptera (Bravo et al., 2017). During the sporulation phase, it produces crystalline protein inclusions, named $\delta$-endotoxins or parasporal crystals (Cry or Cyt) (Aronson et al., 1986), which are solubilized in the gut of the immature stages of insects under alkaline (Lepidoptera and Diptera) or acid (Coleoptera and Hemiptera) $\mathrm{pH}$ (Bravo et al., 2012). Also in the gut, proteases will activate the toxin, causing lysis of the insect epithelial cells leading to its death (Bravo et al., 2012; Jurat-Fuentes \& Crickmore, 2016). This bacterium is easy to handle, does not pollute the environment (Monnerat \& Bravo, 2000), and is safe for mammals (Whiteley \& Schnepf, 1986). Few studies of active Bt strains or toxins have been reported in hemipterans (Porcar et al., 2009) since they are rarely exposed to $\mathrm{Bt}$ toxins present on the plant surface (Chougule \& Bonning, 2012). However, endophytic Bt was recently reported in cotton (Monnerat et al., 2009), coffee (Miguel et al., 2013) and wheat (Tao et al., 2014). Furthermore, several studies on the colonization and translocation of Bt have been performed in beans (Maduell et al., 2007; García-Suárez et al., 2017), cabbage (Monnerat et al., 2009; Praça et al., 2012), many different legumes (Tanuja et al., 2013; Mishra et al., 2017) and bryophytes (Lin et al., 2017). These studies open new perspectives for the use of this bacterium as a biocontrol agent for sap-sucking insects (Jurat-Fuentes \& Jacksony, 2012).

For this reason, the ability of the spore-crystal complex of Bt strains to translocate from the root to the upper parts of the citrus seedlings and, most importantly, their pathogenicity against $D$. citri were assessed. To the best of our knowledge, this is the first study that reports the ability of the spore-crystal complex of Bt strains to translocate and cause mortality in $D$. citri nymphs feeding on citrus young shoots. These results may contribute to the development of new alternatives for $D$. citri management, through bioinsecticide formulations or production of genetically modified citrus plants expressing Cry toxins.

\section{Materials and methods}

\section{Insect colony and citrus seedlings}

For all assays, D. citri third-instar nymphs from a healthy non- $\mathrm{Ca}$. Liberibacter spp. exposed and susceptible colony was collected on Murraya paniculata (L.) Jack (Sapindales: Rutaceae) in the municipality of Piracicaba, São Paulo (SP), Brazil, and maintained for several generations (5 years) in a climate-controlled room $(25 \pm$ $2^{\circ} \mathrm{C}, 60 \% \pm 10 \%$, RH and $14 \mathrm{~L}: 10 \mathrm{D}$ h photoperiod) at Department of Entomology and Acarology at the University of São Paulo, Luiz de Queiroz College of Agriculture (ESALQ/USP), Piracicaba, SP, Brazil. The colony was proven to be CaLas-free by qPCR using the primers and conditions described in Lin et al. (2010). The rearing was performed on seedlings of M. paniculata as described by Parra et al. (2016).

"Pera" sweet orange [Citrus sinensis (L.) Osbeck] 3month old seedlings were grown in citrus containers $(120 \mathrm{~mL})$ with pine bark substrate (Multiplant Citrus ${ }^{\circledR}$, Holambra, SP, Brazil) for assessment of systemic translocation and pathogenicity assays conducted at Centro de 
Citricultura Sylvio Moreira (IAC) and Fund for Citrus Protection (Fundecitrus) located in Cordeirópolis and Araraquara, SP, Brazil, respectively.

\section{Bacillus thuringiensis strains and growth conditions}

For all assays, 3 wild-type and 10 recombinant strains, in addition to water as negative control, were used. Preliminary assays showed that recombinant strain S2210, carrying $c r y 1 A b$, had no effect on the psyllid and, therefore, it was used as a mock control. The wild-type strains were $B$. thuringiensis subsp. kurstaki HD-1 (Btk) (S1450), a standard strain obtained from the collection of B. thuringiensis and Lysinibacillus sphaericus at Pasteur Institute, Paris, France, and B. thuringiensis (S1302) and B. thuringiensis subsp. israelensis (S1989) from the collection of bacteria of invertebrates at Embrapa Genetic Resources and Biotechnology, Brasília, DF, Brazil. The recombinant strains S2211, S2210 (here used as mock), S2209, S2396, S2212, S2036, S2037, S2492, S2038, and S2035 express the individual genes $\operatorname{cry} 1 A a$, crylAb, crylAc, $\operatorname{cry} 1 B, \operatorname{cry} 2 A a, \operatorname{cry} 4 A, \operatorname{cry} 4 B, \operatorname{cry} 10, \operatorname{cry} 11$, and cyt $1 A$, respectively, and are deposited at the collection of bacteria of invertebrates at Embrapa Genetic Resources and Biotechnology. In addition, strain S2032 expressing $g f p$ (green fluorescent protein) gene (Btk::GFP) was used to investigate the uptake and translocation of the bacterium into citrus seedlings (Monnerat et al., 2009). Bt strains were cultivated in Embrapa medium containing specific antibiotics to recombinant strains (Monnerat et al., 2007) in a rotating incubator at $28^{\circ} \mathrm{C}$ and $200 \mathrm{r} / \mathrm{min}$, for $24 \mathrm{~h}$ (for Btk::GFP) or up to $72-76 \mathrm{~h}$ (for other strains used in the assays). Prior to use, each strain was observed under a phase-contrast microscope (Leica Microsystems Co., Wetzlar, Germany) with $1000 \times$ magnification to observe vegetative cells or spore-crystal complex.

\section{Assessment of the Bt translocation into citrus seedlings}

In order to assess the Bt endophytic translocation into citrus seedlings, $10 \mathrm{~mL}$ of a $2.5: 10 \mathrm{Btk}:$ GFP suspension : water was applied to the pine bark substrate, close to the roots of each seedling. The translocation of $\mathrm{Bt}$ from the rhizosphere to the upper young shoots and their acquisition by $D$. citri nymphs feeding on those shoots were assessed $2 \mathrm{~d}$ after inoculation (DAI). Citrus young shoots for both treatments (Btk::GFP and negative controls) were surface sterilized for $2 \mathrm{~min}$ for each solution described: sodium hypochlorite $(2.5 \%)$, ethanol $(70 \%)$, water $(2 \times)$, and macerated in $1 \mathrm{~mL}$ of $\mathrm{NaCl}$ saline solution $(8.5 \mathrm{~g} / \mathrm{L})$. For each treatment, five replicates were used. For isolation of $\mathrm{Bt}$ from the insects, pools of up to five nymphs were collected with the aid of a soft brush, macerated in $200 \mu \mathrm{L}$ of water, and incubated for $12 \mathrm{~min}$ at $80^{\circ} \mathrm{C}$ and $5 \mathrm{~min}$ in ice (Praça et al., 2012). After that, $100 \mu \mathrm{L}$ of both macerated materials were placed in Petri dishes containing Embrapa medium, and the Bt colonies were observed in a fluorescence microscope (Olympus Co., Tokyo, Japan). A similar method was used for nymphs from the control treatment.

Later, the translocation of Bt into "Pera" sweet orange seedlings was assessed with each wild-type, nine recombinant strains, and two negative controls (water without spores and crystals and one recombinant strain $c r y l A b$ ) used on the pathogenicity assays, as described previously. However, the isolation of these $\mathrm{Bt}$ strains from young shoots and dead nymphs were assessed 5 DAI after maceration, plating, and observation of typical $\mathrm{Bt}$ colonies. Individual young shoots (from 6-21 replicates per treatment) and a pool of dead nymphs (containing 2-8 nymphs per tube and 3-10 replicates per treatment) were used for maceration. From the CFU obtained by isolation, a single colony was selected from each replicate/treatment/condition (plant or insect) for the confirmation of the identity and translocation in citrus by PCR using specific primers for each strain (Table 1). The PCR analysis was carried out on a Veriti 96-Well Thermal Cycler (Applied Biosystems Inc., California, USA) with $6.25 \mu \mathrm{L}$ of DreamTaq PCR Master Mix $(2 \times)$ (Thermo Scientific Inc., Massachusetts, USA), $0.3 \mu \mathrm{L}$ of each primer $(0.2 \mu \mathrm{mol} / \mathrm{L})$, and $1 \mu \mathrm{L}$ of the total DNA solution as template. For PCR cycling, the same procedure and analysis previously described were used (Céron et al., 1994; 1995; Bravo et al., 1998; Ibarra et al., 2003; Mendoza et al., 2012). PCR products were visualized in agarose gel electrophoresis (1\%) with ethidium bromide $(0.5 \mathrm{ng} / \mu \mathrm{L})$ in ultraviolet light using a PhotoQuant 300 Imager photodocumentator (GE Healthcare Co., Chalfont, UK).

\section{Pathogenicity of Bt strains against Diaphorina citri third-instar nymphs}

A pilot screening with three Bt wild-type strains, nine recombinant strains, and two negative controls (water and strain $c r y 1 A b$ ) was performed. For this purpose, $10 \mathrm{D}$. citri third-instar nymphs were transferred from $M$. paniculata to each seedling and used as an experimental unit. Then, $10 \mathrm{~mL}$ of a bacterium suspension : water $(2.5: 10)$ was applied to the substrate of each seedling. Water and strain $c r y 1 A b$ were used as controls. For each treatment, 10-35 replicates (seedlings) were used. The assay was kept in a climate-controlled chamber at $24 \pm 2^{\circ} \mathrm{C}, 70 \% \pm 10 \%$ $\mathrm{RH}$, and $14 \mathrm{~L}: 10 \mathrm{D}$ h photoperiod. 
Table 1 Sequences of the primers used in the validation and molecular characterization of the Bt strains.

\begin{tabular}{|c|c|c|c|}
\hline Sequence name & $5^{\prime}-3^{\prime}$ sequence & Expected fragment size (bp) & Reference \\
\hline Cry1Aa & $\begin{array}{l}\text { TGTAGAAGAGGAAGTCTATCCA } \\
\text { TTGGAGCTCTCAAGGTGTAA }\end{array}$ & 246 & Cerón et al. (1994) \\
\hline Cry1Ab & $\begin{array}{l}\text { AACAACTATCTGTTCTTGAC } \\
\text { CTCTTATTATACTTACACTAC }\end{array}$ & 216 & Cerón et al. (1994) \\
\hline Cry1Ac & $\begin{array}{l}\text { GTTAGATTAAATAGTAGTGG } \\
\text { TGTAGGTGGTACTGTTATTG }\end{array}$ & 180 & Cerón et al. (1994) \\
\hline Cry2Aa & $\begin{array}{l}\text { CAAGCGAATATAAGGGAGT } \\
\text { TAGCGCCAGAAGATACCA }\end{array}$ & 470 & Mendoza et al. (2012) \\
\hline Cry1B & $\begin{array}{l}\text { CTTCATCACGATGGAGTAA } \\
\text { CATAATTTGGTCGTTCTGTT }\end{array}$ & $367 / 369$ & Cerón et al. (1994) \\
\hline Cry $4 \mathrm{~A}$ & $\begin{array}{l}\text { TCAAAGATCATTTCAAAATTACATG } \\
\text { CGGCTTGATCTATGTCATAATCTGT }\end{array}$ & 459 & Ibarra et al. (2003) \\
\hline Cry4B & $\begin{array}{l}\text { CGTTTTCAAGACCTAATAATATAATACC } \\
\text { CGGCTTGATCTATGTCATAATCTGT }\end{array}$ & 321 & Ibarra et al. (2003) \\
\hline Cry10 & $\begin{array}{l}\text { TCAATGCTCCATCCAATG } \\
\text { CTTGTATAGGCCTTCCTCCG }\end{array}$ & 348 & Ibarra et al. (2003) \\
\hline Cry11 & $\begin{array}{l}\text { TTAGAAGATACGCCAGATCAAGC } \\
\text { CATTTGTACTTGAAGTTGTAATCCC }\end{array}$ & 305 & Bravo et al. (1998) \\
\hline Gral-cyt & $\begin{array}{l}\text { AACCCCTCAATCAACAGCAAGG } \\
\text { GGTACACAATACATAACGCCACC }\end{array}$ & Cyt1Aa 522/Cyt1Ab 525 & Bravo et al. (1998) \\
\hline Cry3A & $\begin{array}{l}\text { CAATCCCAGTGTTTACTTGGAC } \\
\text { CCCCGTCTAAACTGAGTGT }\end{array}$ & 285 & Cerón et al. (1995) \\
\hline Cry $2 \mathrm{Ab}$ & $\begin{array}{l}\text { CACCTGGTGGAGCACGAG } \\
\text { GTCTACGATGAATGTCCC }\end{array}$ & 771 & Mendoza et al. (2012) \\
\hline Cyt1 & $\begin{array}{l}\text { CCTCAATCAACAGCAAGGGTTATT } \\
\text { TGCAAACAGGACATTGTATGTGTAATT }\end{array}$ & $\begin{array}{c}\text { cyt1Aa 477/cyt1Ab480/cyt1Ba } \\
477\end{array}$ & Ibarra et al. (2003) \\
\hline
\end{tabular}

First line of each primer: forward primer; second line: reverse primer.

A second assay was carried out in order to assess the effect of the most promising Bt strains, following the same procedures and criteria described above. For each treatment, 10 replicates (seedlings) were used. The nymph mortality in each experimental unit and assay was recorded daily for 5 DAI. The dead nymphs from each treatment were collected during the assessments for $\mathrm{Bt}$ isolation to confirm their acquisition by the nymphs through the PCR amplification of CFU using specific primers for each cry and cyt gene described in Table 1.

\section{Experimental design and data analysis}

For all assays, a fully randomized design was used. In order to verify the effect of different Bt strains on the mortality of $D$. citri third-instar nymphs at different times (DAI), they were subjected to a repeated measure analysis using generalized linear mixed models (GLMM) of the "Ime4" package (Bates et al., 2015), with a binomial distribution. For this purpose, the effect of explanatory variables ("Pera" sweet oranges treated with Bt strains and control) and the time were considered as fixed factors, whereas the repeated measure in each seedling in time was considered as random. The effect of treatment and time was assessed by likelihood-ratio tests $(P<0.05)$ between a full and a reduced model. The same test was used to verify the significance of the treatment interaction by time, comparing two models: one with interaction and another without interaction. Furthermore, the effect of $\mathrm{Bt}$ strains on the mortality of $D$. citri nymphs for each time, generalized linear models (GLM) (Nelder \& Wedderrbun, 1972), with quasi-binomial distribution, were used to analyze the proportion of mortality. Goodness-of-fit was assessed through half-normal plots with simulation envelope using the "hnp" package (Demétrio et al., 2014). In 
case of significant differences among treatments, multiple comparisons with the Tukey-Kramer test $(P<0.05)$ were performed using the "glht" function of the "multcomp" package, with adjusted $P$ values (Hothorn et al., 2008). All analysis were performed using the statistical software " $R$," version 3.4.4 (R Core Team, 2018).

\section{Results}

\section{Bt strains and growth conditions}

Phase contrast microscopy with a 1000 fold increase allowed confirming the presence of large numbers of spores and crystals of different forms produced in bacterial suspensions from all Bt strains after $72 \mathrm{~h}$ of culture (Figs. S1A and B). Vegetative cells were rarely observed.

\section{Assessment of the Bt endophytic translocation into citrus seedlings}

The uptake of the bacteria in citrus seedlings and their acquisition by the $D$. citri nymphs that fed on those seedlings were confirmed by the isolation of Btk::GFP from both citrus shoots and insects, yielding variable numbers (between 30 and 100) of CFU with typical whitish cream coloration and irregular borders in Petri dishes containing Embrapa medium (data not shown). There were no colonies observed on the negative control (water) plates. The identity of the bacterium was confirmed by fluorescence microscopy with the presence of fluorescent bacilliform cells (Figs. 1B-C).

Subsequently to the proof of concept for the Btk::GFP strain, the translocation of practically all $\mathrm{Bt}$ strains from the rhizosphere to the citrus young shoots and their acquisition by the $D$. citri nymphs were unequivocally confirmed 5 DAI with the recovery of typical Bt colonies (Fig. S2), followed by PCR assays with specific primers for each cry and cyt gene, detected in all treatments (except for strain S2396) (Table 2 and Fig. S3). Single fragments of expected sizes, ranging from 180 to $522 \mathrm{bp}$, were obtained for the corresponding Bt strains (Fig. S3). The number of $\mathrm{CFU}$ recovered from the $\mathrm{Bt}$ isolation from citrus young shoots and dead nymphs in both assays were variable, and they were classified as follows: (a) low: 1$10 \mathrm{CFU}$, (b) intermediate: 11-30 CFU, and (c) high: more than 30 CFU (Table 2). Twelve out of $13 \mathrm{Bt}$ strains were able to translocate from the roots to the young shoots of citrus and to be acquired by the psyllid nymphs that fed on those shoots. The only strain that failed to translocate properly was S2396, containing crylB. The others were detected in both conditions (plants and insects),

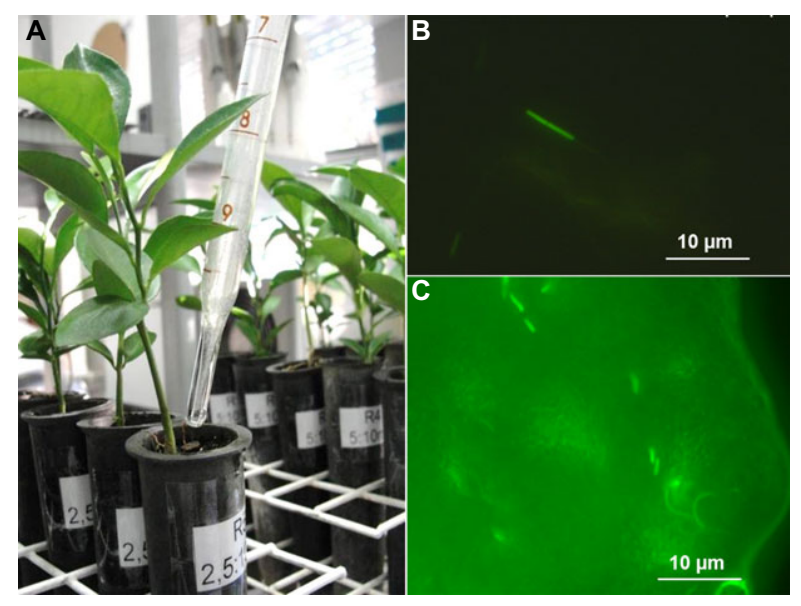

Fig. 1 Inoculation of Btk::GFP suspension in "Pera" sweet orange seedlings (A), recovery and visualization of soil-drench inoculated Btk::GFP vegetative cells in young citrus shoots by fluorescence microscopy under magnifications of $1000 \times$ (B) and $400 \times(\mathrm{C})$.

although most of the strains yielded a low number of colonies (S1302, S1450, S1989, S2210, S2212, S2037, $\mathrm{S} 2492)$. Bt strains with intermediate numbers of colonies were S2211, S2209, S2036, and S2035, and only S2038 yielded a high number of colonies from both plants and insects (Figs. S2B-S2G). The identities of the Bt strains from the colonies were confirmed by PCR (Table 2 and Fig. S3).

\section{Pathogenicity of Bt strains against Diaphorina citri third-instar nymphs}

A significant interaction between treatment and time (DAI) was recorded for the initial screening $\left(\chi^{2}=27.03\right.$; $\mathrm{df}=13 ; P<0.0001)$ and also for the second assay $\left(\chi^{2}=\right.$ 58.23; $\mathrm{df}=8 ; P<0.0001)$, indicating that the mortality rates provided by different Bt strains to $D$. citri third-instar nymphs increased over time (Tables 3 and 4 ).

In the initial screening, water and mock strain cryl $\mathrm{Ab}$ caused mortality from $14.4 \%$ to $33 \%$ at 5 DAI, respectively. Strains S1302, S1450, and S1989 caused 55\%-77\% mortality of $D$. citri nymphs at $2 \mathrm{DAI}$, and $77 \%-90 \%$ mortality at 5 DAI (Table 3 ). The recombinant strains containing the genes crylAa, cry $2 A a$, cry $4 B$, cryl0, cryll, or $c y t 1 A$ were also pathogenic to $D$. citri nymphs, reaching 50\%-65\% mortality at 5 DAI (Table 3). Strain S1302 harbors the genes $c r y 1 A b$ and $c r y 3 A$, strain S1450 carries genes crylAa, crylAb, crylAc, crylAc, cry $2 A a$, and cry $2 A b$, whereas strain S1989 contains the genes cry $4 A$, $\operatorname{cry} 4 B, \operatorname{cry} 10, \operatorname{cry} 11, \operatorname{cyt} 1 A$, and $c y t 1 B$. Ten out of those 
Table 2 Confirmation of Bt identity by isolation followed by PCR with each $c r y / c y t$ genes.

\begin{tabular}{|c|c|c|}
\hline Treatments/ initial screening & $\begin{array}{c}{ }^{\dagger} \text { UFC range obtained in isolation of young shoots } \\
\text { (6-21 replicates)/dead nymphs pool ( } 2-8 \\
\text { nymphs/tube-3-10 replicates per treatment) }\end{array}$ & $\begin{array}{c}\text { PCR for young shoots/dead } \\
\text { nymphs pool }\end{array}$ \\
\hline S1302 & Few/few & $+/+$ \\
\hline S1450 & Few/few & $+/+$ \\
\hline S1989 & Few/few & $+/+$ \\
\hline crylAa & Few/mean & $+/+$ \\
\hline $\operatorname{cry} 1 A c$ & Many/few & $+/+$ \\
\hline $\operatorname{cry} 2 \mathrm{Aa}$ & Few/few & $+/+$ \\
\hline $\operatorname{cry} 1 B$ & Without growth/poor growth & $-1+$ \\
\hline $\operatorname{cry} 4 A$ & Few/many & $+/+$ \\
\hline $\operatorname{cry} 4 B$ & Few/few & $+/+$ \\
\hline crylo & Few/few & $+/+$ \\
\hline $\operatorname{cry} 11$ & Many/many & $+/+$ \\
\hline$c y t 1 A$ & Few/many & $+/+$ \\
\hline$c r y l A b$ & Few/few & $+/+$ \\
\hline Negative Control & Without growth/without growth & $-1-$ \\
\hline Treatments/assay II & $\begin{array}{l}{ }^{\dagger} \text { UFC range obtained in isolation of young shoots } \\
\text { (6-21 replicates)/dead nymphs pool (2-8 } \\
\text { nymphs/tube-3-10 replicates per treatment) }\end{array}$ & $\begin{array}{l}\text { PCR for young shoots/ dead } \\
\text { nymphs pool }\end{array}$ \\
\hline S1302 & Mean & $+/+$ \\
\hline S1450 & Mean & \\
\hline S1989 & Mean & $+/+$ \\
\hline $\operatorname{cry} 2 A a$ & Mean & $+/+$ \\
\hline $\operatorname{cry} 4 A$ & Mean & $+/+$ \\
\hline $\operatorname{cry} 10$ & Mean & $+/+$ \\
\hline $\operatorname{cry} 11$ & Mean & $+/+$ \\
\hline $\operatorname{cyt} 1 \mathrm{~A}$ & Mean & $+/+$ \\
\hline Negative control & Without growth & $-1-$ \\
\hline
\end{tabular}

${ }^{\dagger}$ UFC number range (average). Low: 1-10, intermediate: 11-30, and high: more than 30.

13 toxin genes were represented in the recombinant strains and tested individually, causing different toxicity levels to the citrus psyllid nymphs. The strains containing genes cry $4 B$, cry 10, cry 11 , and $c y t 1 A$ caused $60 \%-65 \%$ mortality of $D$. citri nymphs at 5 DAI. These genes are present in strain S1989, which was responsible for the death of up to $79 \%$ and $88 \%$ of the D. citri nymphs at 2 DAI and 5 DAI, respectively (Table 3 and Fig. S4). Strains Cry1Aa and Cry2Aa caused $\sim 50 \%$ mortality, while strains Cry $1 \mathrm{Ab}$, Cry1Ac, and Cry4A were able to cause mortality from $36 \%$ to $44 \%$ of insects at 5 DAI (Table 3 ). Although statistical analyses detected significant differences between these strains and the control treatment, from the biological point of view, they are not effective in controlling the $D$. citri nymphs, and therefore, they were not further assessed. Strains Cry1Ab and Cry1B did not differ from the water control (Table 3).
With the results obtained in the screening of 13 strains tested, the best wild-type and recombinant strains (S1302, S1450, S1989, Cry2Aa, Cry10, Cry11, and Cyt1A) that yielded mortality above $50 \%$ and at least one strain with a mortality of less than $50 \%$ (Cry4A) were selected for a new assessment (Table 4). Similar results were obtained in assay 2. In this case, the mortality observed in D. citri were lower than those originally observed in the wild-type strains (S1302, S1450, and S1989), and the recombinant strains (Cry2Aa, Cry4A, Cry11, and Cyt1A) at 5 DAI, but the pathogenicity of the Bt strains was confirmed (Table 4). Moreover, strains S1450, S1302, and Cry10 confirmed their ability to cause mortality to the psyllids in the second assay as well (Table 4).

The association between Bt strains and nymphal mortality was confirmed by the recovery of typical Bt colonies from dead nymphs and PCR amplification with specific 
Table 3 Initial screening of mortality of Diaphorina citri third-instar nymphs when "Pera" sweet orange seedlings were systemically treated with a suspension of Bacillus thuringiensis.

\begin{tabular}{|c|c|c|c|c|c|}
\hline \multirow{2}{*}{ Treatment } & \multicolumn{5}{|c|}{ Mortality $^{\dagger}(\%) /$ days after Bt application and nymph transfer (DAI) } \\
\hline & 1 & 2 & 3 & 4 & 5 \\
\hline S1302 & $56.0 \pm 7.33 \mathrm{a}$ & $77.0 \pm 7.61 \mathrm{a}$ & $85.0 \pm 6.01 \mathrm{a}$ & $88.0 \pm 6.29 \mathrm{a}$ & $90.0 \pm 5.96 \mathrm{a}$ \\
\hline $\mathrm{S} 1450$ & $29.0 \pm 9.24 \mathrm{ab}$ & $55.0 \pm 9.46 \mathrm{a}$ & $64.0 \pm 10.02 \mathrm{ab}$ & $74.0 \pm 7.02 \mathrm{ab}$ & $77.0 \pm 6.67 \mathrm{ab}$ \\
\hline S1989 & $57.0 \pm 11.55 \mathrm{a}$ & $69.0 \pm 11.00 \mathrm{a}$ & $75.0 \pm 9.69 \mathrm{ab}$ & $81.0 \pm 7.06 \mathrm{ab}$ & $82.0 \pm 6.96 \mathrm{ab}$ \\
\hline Cry1Aa & $24.7 \pm 8.56 \mathrm{ab}$ & $36.7 \pm 8.82 \mathrm{ab}$ & $44.0 \pm 9.09 \mathrm{ab}$ & $46.0 \pm 8.83 \mathrm{ab}$ & $50.0 \pm 8.94 \mathrm{ab}$ \\
\hline CrylAc & $25.0 \pm 10.25 \mathrm{ab}$ & $33.0 \pm 10.55 \mathrm{ab}$ & $35.0 \pm 10.88 \mathrm{~b}$ & $40.0 \pm 10.00 \mathrm{~b}$ & $44.0 \pm 9.91 \mathrm{~b}$ \\
\hline Cry1B & $14.0 \pm 4.76 \mathrm{~b}$ & $15.0 \pm 5.00 \mathrm{bc}$ & $17.0 \pm 4.96 \mathrm{bc}$ & $21.0 \pm 5.86 \mathrm{bc}$ & $26.0 \pm 5.81 \mathrm{bc}$ \\
\hline Cry2Aa & $30.0 \pm 9.31 \mathrm{ab}$ & $38.7 \pm 9.90 \mathrm{ab}$ & $43.3 \pm 9.64 \mathrm{ab}$ & $44.7 \pm 9.85 \mathrm{ab}$ & $51.3 \pm 9.35 \mathrm{ab}$ \\
\hline Cry4A & $14.5 \pm 4.00 \mathrm{~b}$ & $21.0 \pm 5.71 \mathrm{~b}$ & $26.0 \pm 6.04 \mathrm{bc}$ & $31.0 \pm 6.28 \mathrm{bc}$ & $36.0 \pm 5.82 \mathrm{~b}$ \\
\hline Cry4B & $43.5 \pm 7.99 \mathrm{ab}$ & $54.5 \pm 7.80 \mathrm{a}$ & $56.0 \pm 7.66 \mathrm{ab}$ & $59.5 \pm 7.38 \mathrm{ab}$ & $62.0 \pm 7.06 \mathrm{ab}$ \\
\hline Cry10 & $50.0 \pm 6.45 \mathrm{a}$ & $56.5 \pm 7.04 \mathrm{a}$ & $60.0 \pm 6.96 \mathrm{ab}$ & $62.0 \pm 6.59 \mathrm{ab}$ & $65.0 \pm 5.83 \mathrm{ab}$ \\
\hline Cry11 & $35.1 \pm 5.22 \mathrm{ab}$ & $46.6 \pm 5.90 \mathrm{ab}$ & $53.7 \pm 6.14 \mathrm{ab}$ & $56.3 \pm 6.20 \mathrm{ab}$ & $60.0 \pm 5.94 \mathrm{ab}$ \\
\hline Cyt1A & $44.0 \pm 9.80 \mathrm{ab}$ & $51.3 \pm 9.10 \mathrm{a}$ & $52.7 \pm 8.97 \mathrm{ab}$ & $58.7 \pm 8.22 \mathrm{ab}$ & $62.0 \pm 8.00 \mathrm{ab}$ \\
\hline Cry1Ab & $9.0 \pm 3.48 \mathrm{~b}$ & $17.0 \pm 4.96 \mathrm{bc}$ & $25.0 \pm 6.87 \mathrm{bc}$ & $28.0 \pm 8.14 \mathrm{bc}$ & $33.0 \pm 8.70 \mathrm{bc}$ \\
\hline Control & $1.1 \pm 0.50 \mathrm{~b}$ & $3.3 \pm 0.90 \mathrm{c}$ & $8.0 \pm 1.57 \mathrm{c}$ & $11.1 \pm 1.92 \mathrm{c}$ & $14.4 \pm 2.06 \mathrm{c}$ \\
\hline$F$ & 11.26 & 13.073 & 11.863 & 12.189 & 12.351 \\
\hline df & 13,241 & 13,241 & 13,241 & 13,241 & 13,241 \\
\hline$P$-value & $<0.0001$ & $<0.0001$ & $<0.0001$ & $<0.0001$ & $<0.0001$ \\
\hline
\end{tabular}

${ }^{\dagger}$ Data (mean $\pm \mathrm{SE}$ ) followed by the same letter in a column do not differ statistically (GLM with a quasi-binomial distribution, followed by post hoc Tukey-Kramer test; $P<0.05)$.

primers for the cry or cyt genes present in the tested strains (Table 2). The exception was strain crylB, which exhibited very poor translocation within the plant, yielding no colonies from the seedlings macerate and with a single colony from the psyllid macerate. For the other strains, few but consistent CFUs were obtained from the isolation of $\mathrm{Bt}$ colonies from dead nymphs and citrus shoots, and single fragments of expected sizes, ranging from 180 to $522 \mathrm{bp}$ (see Table 1) were observed after PCR with specific primer pairs (Fig. S3). In most cases, data unambiguously confirmed the identity of the Bt strains and their ability to translocate within citrus seedlings.

\section{Discussion}

The morphological characterization of the Bt inocula just prior to setting up the assays was important to confirm the presence of $\mathrm{Bt}$ spores and crystals, recommended for a good inoculum (Johnson et al., 1998; Rabinovitch et al., 2017; Mukhija \& Khanna, 2018). The capacity of Bt strains to reach young shoots of citrus after being inoculated to the seedling roots and be acquired by $D$. citri nymphs that fed on them was demonstrated by the isolation and plating of $\mathrm{Bt}$ and recuperation of CFU followed by the detection of cry or cyt gene present in each strain by PCR with specific primers, except in the control treatment. The detection of the cry or cyt genes present in each of the analyzed strains was consistent for all PCR assays and replicates (from 6 to 21) selected for each strain isolated from either young shoots or dead nymphs. Therefore, although the amount of toxin ingested by the insects may be variable, the proof of concept was obtained in all of the treatments, which means that, although standardization can be improved, the possibility of using $\mathrm{Bt}$ for the control of $D$. citri is promising.

These results are consistent with studies that confirmed Bt translocation and colonization in cotton seedlings (Monnerat et al., 2009; Melatti et al., 2010), cabbage (Monnerat et al., 2009; Praça et al., 2012), legumes (Tanuja et al., 2013), beans (García-Suárez et al., 2017), Arabidopsis (Vidal-Quist et al., 2013; García-Suárez et al., 2017), and bryophytes (Lin et al., 2017), and their acquisition by insects feeding on those plants (Monnerat et al., 2009; Melatti et al., 2010; García-Suárez et al., 2017). In these studies, the Bt structures (vegetative cells, spores, and crystals) were recovered from the plants by the isolation of one to several tissues (leaves, petioles, stems, roots). At least in cotton, cabbage, beans, and bryophytes, the bacteria were visualized by fluorescence and electron 
Table 4 Evaluation of mortality of Diaphorina citri third-instar nymphs, in assay II, when "Pera" sweet orange seedlings were systemically treated with Bacillus thuringiensis strains.

\begin{tabular}{lccccc}
\hline & \multicolumn{5}{c}{ Mortality $^{\dagger}(\%)$ /days after Bt application and nymph transfer (DAI) } \\
\cline { 2 - 6 } Treatment & 1 & 2 & 3 & 4 & 5 \\
\hline S1302 & $26.0 \pm 4.00 \mathrm{ab}$ & $42.0 \pm 1.33 \mathrm{~b}$ & $56.0 \pm 3.40 \mathrm{a}$ & $66.0 \pm 3.40 \mathrm{a}$ & $68.0 \pm 3.27 \mathrm{a}$ \\
$\mathrm{S} 1450$ & $34.0 \pm 2.67 \mathrm{ab}$ & $52.0 \pm 2.49 \mathrm{a}$ & $56.0 \pm 1.63 \mathrm{a}$ & $66.0 \pm 3.40 \mathrm{a}$ & $70.0 \pm 2.11 \mathrm{a}$ \\
S1989 & $30.0 \pm 2.98 \mathrm{ab}$ & $34.0 \pm 1.63 \mathrm{~b}$ & $36.0 \pm 1.63 \mathrm{~b}$ & $38.0 \pm 1.33 \mathrm{bc}$ & $42.0 \pm 2.49 \mathrm{c}$ \\
Cry2Aa & $16.0 \pm 1.63 \mathrm{bc}$ & $18.0 \pm 2.49 \mathrm{c}$ & $22.0 \pm 2.49 \mathrm{c}$ & $34.0 \pm 2.67 \mathrm{c}$ & $36.0 \pm 2.67 \mathrm{~cd}$ \\
Cry4A & $28.0 \pm 3.89 \mathrm{ab}$ & $32.0 \pm 3.89 \mathrm{~b}$ & $34.0 \pm 3.40 \mathrm{~b}$ & $34.0 \pm 3.40 \mathrm{c}$ & $40.0 \pm 2.11 \mathrm{~cd}$ \\
Cry10 & $40.0 \pm 2.11 \mathrm{a}$ & $54.0 \pm 1.63 \mathrm{a}$ & $56.0 \pm 2.67 \mathrm{a}$ & $58.0 \pm 2.49 \mathrm{a}$ & $66.0 \pm 1.63 \mathrm{a}$ \\
Cry11 & $26.0 \pm 2.67 \mathrm{ab}$ & $32.0 \pm 2.49 \mathrm{~b}$ & $34.0 \pm 2.67 \mathrm{~b}$ & $34.0 \pm 2.67 \mathrm{c}$ & $41.0 \pm 3.14 \mathrm{~cd}$ \\
Cyt1A & $24.0 \pm 3.40 \mathrm{~b}$ & $34.0 \pm 3.40 \mathrm{~b}$ & $38.0 \pm 2.49 \mathrm{~b}$ & $48.0 \pm 3.89 \mathrm{~b}$ & $54.0 \pm 3.40 \mathrm{~b}$ \\
Control & $10.0 \pm 2.11 \mathrm{c}$ & $24.0 \pm 1.63 \mathrm{c}$ & $30.0 \pm 2.11 \mathrm{~b}$ & $30.0 \pm 2.11 \mathrm{c}$ & $30.0 \pm 2.11 \mathrm{~d}$ \\
$F$ & 9.515 & 21.392 & 22.910 & 23.424 & 8,81 \\
df & 8,81 & 8,81 & 8,81 & $<0.0001$ & 8,81 \\
$P$-value & $<0.0001$ & $<0.0001$ & $<0.0001$ & $<0.0001$ \\
\hline
\end{tabular}

${ }^{\dagger}$ Data (mean \pm SE) followed by the same letter in a column do not differ statistically (GLM with a quasi-binomial distribution, followed by post hoc Tukey test; $P<0.05)$.

microscopy (Monnerat et al., 2009; Praça et al., 2012; García-Suárez et al., 2017). In cabbage, it was suggested that the entry of $\mathrm{Bt}$ occurred through cracks present in the roots and migrated to the leaves through the xylem (Monnerat et al., 2009; Praça et al., 2012; García-Suárez et al., 2017).

In citrus, it is likely that this also occurs. It has been reported that $D$. citri, after periods of fasting, can feed on the xylem vessels in search of water (Bonani et al., 2010). With the detection of $\mathrm{Bt}$ translocation in citrus seedlings, prospects of its use in the control of phloem-feeding insects are now opened. A total of $13 \mathrm{Bt}$ strains were tested against $D$. citri nymphs in two large assays and strains S1450 and S1302 provided high mortality rates (68\%$90 \%$ ) of $D$. citri nymphs at $5 \mathrm{DAI}$, followed by recombinant Cry 10 and Cyt1A strains, which caused 54\%-66\% nymphal mortality.

When recombinant strains containing single cry or cyt gene were inoculated and tested individually, they tended to exhibit lower mortality rates when compared to the wild-type strains. For example, strain S1302 harbors only two genes, $c r y 1 A b$ and $c r y 3 A$, and the mortality of $D$. citri nymphs reached up to $90 \%$ at 5 DAI. The recombinant cry $1 \mathrm{Ab}$ strain was able to kill only $33 \%$ of the nymphs. Hence, the mortality observed in D. citri nymphs may be likely attributed to the action of the $c r y 3 A$ gene (not available for individual testing) or the synergistic interaction between $c r y 3 A$ and $c r y l A b$. These two genes have been shown to cause negative effects on Acyrthosiphon pisum
Harris (Hemiptera: Aphididae) survival and development (Porcar et al., 2009), and on Macrosiphum euphorbiae (Thomas) (Hemiptera: Aphididae) (Walters \& English, 1995). In addition, an increase in activity and toxicity of these (Cry1 Ab and Cy3A) and other (Cry11 and Cry4) toxins was observed in the presence of activated trypsin in vitro and when the aphids were exposed to $500 \mu \mathrm{g} / \mathrm{mL}$ of the solubilized protein, from $3 \mathrm{~d}$ of exposure (Porcar et al., 2009).

The results obtained for strain S1450, when compared to those observed for the recombinant strains harboring the single genes $c r y l A b, c r y l A c, c r y l B, c r y l A a$, or cry $2 A a$, were analogous to the data obtained for strain S1302. While the wild-type strain caused up to $77 \%$ mortality in $D$. citri nymphs at 5 DAI, the individual genes tested did not have a significant effect on the psyllid. Unfortunately, $c r y 2 A b$ was not available for individual testing and, therefore, that may be the main toxin responsible for the insect high mortality rate observed in the wild-type strain harboring that gene. Interestingly, $c r y l A b$ and $c r y l A c$ genes are among the most commonly used in the production of transgenic $\mathrm{Bt}$ cotton and $\mathrm{Bt}$ corn, respectively, for the control of caterpillars (Sheikh et al., 2017), but not for hemipterans.

In this study, mortality rates from $60 \%$ to $65 \%$ of $D$. citri nymphs were obtained at $5 \mathrm{DAI}$, in both assays, when strains harboring individual cry $4 B$, cry 10, cry 11 , or cyt $1 A$ genes were tested. The $\operatorname{cry} 4 A$ strain, also present in the wild-type strain S1989, was responsible for causing the 
death of only $36 \%-40 \%$ of the nymphs at 5 DAI. Since strain S1989 was able to control up to $82 \%$ of the $D$. citri nymphs at five DAI, this effect may be the sum or even the synergistic interaction between cry $4 A, c r y 4 B$, cry 10 , cry 11 , and cyt1A. Particularly for the wild-type strains S1302, S1989, and the recombinant strain cry11, a change in mortality was observed between the first and the second assays. This variation may be attributed to the standardization of the number of spores and crystals of the inoculum, or the amount of $\mathrm{Bt}$ acquired by the insect during feeding, which can be variable due to its systemic distribution within the plant. It is important to notice that, as expected, the number of colonies recovered by the Bt isolation in Petri dishes did not correlate directly with nymphal mortality, suggesting that mortality rates are not related with the sole presence of the bacteria, but likely with specific toxins they produce. It should be also noted that preliminary Cry toxins binding assays with $D$. citri brush border membrane vesicle (BBMV) obtained from nymphs showed binding between toxins present in $\mathrm{Bt}$ strains used in the pathogenic assays and receptors present in BBMV from the psyllid (data not shown).

In summary, this is the first effort to identify and characterize $\mathrm{Bt}$ strains and genes able to cause mortality in $D$. citri nymphs. Up till now, the few studies on the use of $\mathrm{Bt}$ to control phloem-feeding hemipteran insects were concentrated on aphids (Melatti et al., 2010; Chougule et al., 2013). For the first time, we confirmed the ability of Bt strains to translocate from roots to shoots in citrus seedlings, and cause high mortality of $D$. citri nymphs feeding on them. Furthermore, PCR allows rapid identification of $\mathrm{Bt}$ strains and toxin genes, and it has been successfully used in this and other studies (Monnerat et al., 2009; Praça et al., 2013; Nair et al., 2018). PCR of Bt colonies with the specific primers used in this work allowed to unequivocally confirm the identity of the strain, and also confirmed the cause of nymphal mortality observed in our assays. The confirmation of the endophytic capacity of Bt in citrus, and the identification of Bt strains and toxins pathogenic to D. citri suggest that either classical biological control or transgenic Bt citrus could be employed as one more tool in the management of HLB, the most important disease of the citriculture worldwide.

\section{Acknowledgments}

This study was financed in part by the Coordenação de Aperfeiçoamento de Pessoal de Nível SuperiorBrasil (CAPES) and by the Brazilian Agricultural Research Corporation (EMBRAPA — grant number
03.13.03.006.00.00). The authors thank to CAPES for the scholarships associated with the first author of this research. The authors also thank Dr. Valdenice M. Novelli for providing laboratory and greenhouse space for the performance of the assays.

\section{Author contributions}

$\mathrm{SD}, \mathrm{JB}$, and JA contributed with the conception and design of the study; SD, JB, and TC performed the experiments; $\mathrm{SD}, \mathrm{TC}, \mathrm{OZ}, \mathrm{MP}$, and JA analyzed the data; OZ performed the statistical analysis; JA, RM, MP, JL, and MM provided guidance and contributed with reagents, materials, and infrastructure; SD, TC, OZ, MP, and JA wrote sections of the manuscript. All authors contributed to the manuscript revision, read, and approved the submitted version.

\section{Disclosure}

The authors declare that there is no conflict of interest on both sides.

\section{References}

Aronson, A.I., Beckman, W. and Dunn, P. (1986) Bacillus thuringiensis and related insect pathogens. Microbiological Reviews, 50, 1-24.

Ausique, J.J.S., D’Alessandro, C.P., Conceschi, M.R., Mascarin, G.M. and Delalibera Júnior, I. (2017) Efficacy of entomopathogenic fungi against adult Diaphorina citri from laboratory to field applications. Journal of Pest Science, 90, 947-960.

Bassanezi, R.B., Montesino, L.H., Gimenes-Fernandes, N., Yamamoto, P.T., Gottwald, T.R., Amorim, L., et al. (2013) Efficacy of area-wide inoculum reduction and vector control on temporal progress of huanglongbing in young sweet orange plantings. Plant Disease, 97, 789-796.

Bates, D., Mächler, M., Bolker, B. and Walker, S. (2015) Fitting linear mixed-effects models using lme4. Journal of Statistical Software, 67, 1-48.

Belasque Junior, J., Bassanezi, R.B., Yamamoto, P.T., Ayres, A.J., Tachibana, A., Violante, A.R., et al. (2010) Lessons from huanglongbing management in São Paulo state, Brazil. Journal of Plant Pathology, 92, 285-302.

Boina, D.R. and Bloomquist, J.R. (2015) Chemical control of the Asian citrus psyllid and of huanglongbing disease in citrus. Pest Management Science, 71, 808-823.

Bonani, J.P., Fereres, A., Garzo, E., Miranda, M.P., Appezzatoda-Gloria, B. and Lopes, J.R.S. (2010) Characterization of electrical penetration graphs of the Asian citrus psyllid, 
Diaphorina citri, in sweet orange seedlings. Entomologia Experimentalis et Applicata, 134, 35-49.

Bravo, A., Gómez, I., Porta, H., García-Gómez, B.I., RodriguezAlmazan, C., Pardo, L., et al. (2012) Evolution of Bacillus thuringiensis Cry toxins insecticidal activity. Microbial Biotechnology, 6, 17-26.

Bravo, A., Pacheco, S., Gómez, I., Garcia-Gómez, B., Onofre, J. and Soberón, M. (2017) Insecticidal proteins from Bacillus thuringiensis and their mechanism of action. Bacillus thuringiensis and Lysinibacillus sphaericus Characterization and Use in the Field of Biocontrol (eds. L.M. Fiuza, K.R.A. Polanczy \& N. Crickmore), pp. 53-66. Springer, Cham.

Bravo, A., Sarabia, S., Lopez, L., Ontiveros, H., Abarca, C., Ortiz, A., et al. (1998) Characterization of cry genes in a Mexican Bacillus thuringiensis strain collection. Applied and Environmental Microbiology, 64, 4965-4972.

Cerón, J., Covarrubias, L., Quintero, R., Ortiz, A., Ortiz, M., Aranda, E., et al. (1994) PCR analysis of the cryI insecticidal crystal family genes from Bacillus thuringiensis. Applied and Environmental Microbiology, 60, 353-356.

Cerón, J., Ortíz, A., Quintero, R., Güereca, L. and Bravo, A. (1995) Specific PCR primers directed to identify cryI and cryIII genes within a Bacillus thuringiensis strain collection. Applied and Environmental Microbiology, 61, 3826-3831.

Chougule, N.P. and Bonning, B.C. (2012) Toxins for transgenic resistance to hemipteran pests. Toxins, 4, 405-429.

Chougule, N.P., Li, H., Liu, S., Linz, L.B., Narva, K.E., Meade, T., et al. (2013) Retargeting of the Bacillus thuringiensis toxin Cyt2Aa against hemipteran insect pests. Proceedings of the National Academy of Sciences USA, 110, 8465-8470.

Cifuentes-Arenas, J.C., Goes, A., Miranda, M.P., Beattie, G.A.C. and Lopes, S.A. (2018) Citrus flush shoot ontogeny modulates biotic potential of Diaphorina citri. PLoS ONE, 13, 1-17.

Conceschi, M.R., D’Alessandro, C.P., Moral, R.A., Demétrio, C.G.B. and Delalibera-Júnior, I. (2016) Transmission potential of the entomopathogenic fungi Isaria fumosorosea and Beauveria bassiana from sporulated cadavers of Diaphorina citri and Toxoptera citricida to uninfected D. citri adults. BioControl, 61, 567-577.

Demétrio, C.G.B., Hinde, J. and Moral, R.A. (2014) Models for overdispersed data in entomology. Ecological Modeling Applied to Entomology (eds. C.P. Ferreira \& W.A.C. Godoy), pp. 219-259. Springer, Cham.

El-Shesheny, I., Hajeri, S., El-Hawary, I., Gowda, S. and Killiny, N. (2013) Silencing abnormal wing disc gene of the Asian citrus psyllid, Diaphorina citri disrupts adult wing development and increases nymph mortality. PLoS ONE, 8, e65392.

Flores, D. and Ciomperlik, M. (2017) Biological control using the ectoparasitoid, Tamarixia radiata, against the Asian citrus psyllid, Diaphorina citri, in the lower Rio Grande Valley of Texas. Southwestern Entomologist, 42, 49-59.
Galdeano, D.M., Breton, M.C., Lopes, J.R.S., Falk, B.W. and Machado, M.A. (2017) Oral delivery of double-stranded RNAs induces mortality in nymphs and adults of the Asian citrus psyllid, Diaphorina citri. PLoS ONE, 12, e0171847.

García-Suárez, R., Verduzco-Rosas, L.A., Del Rincón-Castro, M.C., Délano-Frier, J. and Ibarra, J.E. (2017) Translocation of Bacillus thuringiensis in Phaseolus vulgaris tissues and vertical transmission in Arabidopsis thaliana. Journal of Applied Microbiology, 122, 1092-1100.

Gottwald, T.R. (2010) Current epidemiological understanding of citrus huanglongbing. Annual Review of Phytopathology, 48, 119-139.

Grafton-Cardwell, B., Stelinski, L.L. and Stansly, P.A. (2013) Biology and management of Asian citrus psyllid, vector of huanglongbing pathogens. Annual Review of Entomology, 58, 413-432.

Hall, D.G., Richardson, M.L., El-Desouky, A. and Halbert, S.E. (2012) Asian citrus psyllid, Diaphorina citri, vector of citrus huanglongbing disease. Entomologia Experimentalis et Applicata, 146, 207-223.

Hothorn, T., Bretz, F. and Westfall, P. (2008) Simultaneous inference in general parametric models. Biometrical Journal, 50, 346-363.

Ibarra, J.E., Del Rincón, M.C., Ordúz, S., Noriega, D., Benintende, G., Monnerat, R., et al. (2003) Diversity of Bacillus thuringiensis strains from Latin America with insecticidal activity against different mosquito species. Applied and Environmental Microbiology, 69, 5269-5274.

Inoue, H., Ohnishi, J., Ito, T., Tomimura, K., Miyata, S., Iwanami, T., et al. (2009) Enhanced proliferation and efficient transmission of Candidatus Liberibacter asiaticus by adult $D i$ aphorina citri after acquisition feeding in the nymphal stage. Annals of Applied Biology, 155, 29-36.

Johnson, D.E., Oppert, B. and McGaughey, W.H. (1998) Spore coat protein synergizes Bacillus thuringiensis crystal toxicity for the Indian meal moth (Plodia interpunctella). Current Microbiology, 36, 278-282.

Jouzani, G.S., Valijanian, E. and Sharafi, R. (2017) Bacillus thuringiensis: a successful insecticide with new environmental features and tidings. Applied Microbiology and Biotechnology, 101, 2691-2711.

Jurat-Fuentes, J.L. and Crickmore, N. (2016) Specificity determinants for Cry insecticidal proteins: Insights from their mode of action. Journal of Invertebrate Pathology, 142, 5-10.

Jurat-Fuentes, J.L. and Jacksony, T.A. (2012) Bacterial entomopathogens. Insect Pathology (eds. F.E. Vega \& H.K. Kaya), pp. 265-349. Academic Press, Amsterdam.

Lin, H., Chen, C., Doddapaneni, H., Duan, Y., Civerolo, E. L., Bai, X., et al. (2010) A new diagnostic system for ultrasensitive and specific detection and quantification of Candidatus Liberibacter asiaticus, the bacterium associated with 
citrus Huanglongbing. Journal of Microbiological Methods, 81, 17-25.

Lin, Q.Q., Zhu, P.L., Carballar-Lejarazú, R., Gelbič, I., Guan, X., $\mathrm{Xu}, \mathrm{L}$., et al. (2017) The colonization of Bacillus thuringiensis strains in bryophytes. Turkish Journal of Biology, 41, 41-48.

Maduell, P., Armengol, G., Llagostera, M., Lindow, S. and Orduz, S. (2007) Immigration of Bacillus thuringiensis to bean leaf from soil inoculum or distal plant parts. Journal of Applied Microbiology, 103, 2593-2600.

Melatti, V.M., Praça, L.B., Martins, E.S., Sujii, E., Berry, C. and Monnerat, R.G. (2010) Selection of Bacillus thuringiensis strains toxic against cotton aphid, Aphis gossypii Glover (Hemiptera: Aphididae). BioAssay, 5, 1-4.

Mendoza, G., Portillo, A., Arias, E., Ribas, R.M. and Olmos, J. (2012) New combinations of cry genes from Bacillus thuringiensis strains isolated from northwestern Mexico. International Microbiology, 15, 209-216.

Miguel, P.S.B., Delvaux, J.C., Oliveira, M.N.V., Monteiro, L.C.P., Freitas, F.S., Costa, M.D., et al. (2013) Diversity of endophytic bacteria in the fruits of Coffea canephora. African Journal of Microbiology Research, 7, 586-594.

Miranda, M.P., Yamamoto, P.T., Garcia, R.B., Lopes, J.P.A. and Lopes, J.R.S. (2016) Thiamethoxam and imidacloprid drench applications on sweet orange nursery trees disrupt the feeding and settling behavior of Diaphorina citri (Hemiptera: Liviidae). Pest Management Science, 72, 1785-1793.

Mishra, P.K., Bisht, S.C., Ruwari, P., Subbanna, A.N.S., Bisht, J.K., Bhatt, J.C., et al. (2017) Genetic diversity and functional characterization of endophytic Bacillus thuringiensis isolates from the North Western Indian Himalayas. Annals of Microbiology, 67, 143-155.

Monnerat, R.G., Batista, A.C., Medeiros, P.T., Martins, E.S., Melatti, V.M., Praça, L.B., et al. (2007) Screening of Brazilian Bacillus thuringiensis isolates active against Spodoptera frugiperda, Plutella xylostella and Anticarsia gemmatalis. Biological Control, 41, 291-295.

Monnerat, R.G. and Bravo, A. (2000) Proteínas bioinseticidas produzidas pela bactéria Bacillus thuringiensis: modo de ação e resistência. Controle Biológico (eds. I.S. Melo \& J.L. Azevedo), pp. 163-200. Embrapa Meio Ambiente, Jaguariúna.

Monnerat, R.G., Soares, C.M., Capdeville, G., Jones, G., Martins, E.S., Praça, L., et al. (2009) Translocation and insecticidal activity of Bacillus thuringiensis bacteria living inside of plants. Microbial Biotechnology, 2, 512-520.

Monzo, C., Qureshi, J.A. and Stansly, P.A. (2014) Insecticide sprays, natural enemy assemblages and predation on Asian citrus psyllid, Diaphorina citri (Hemiptera: Psyllidae). Bulletin of Entomological Research, 104, 576-585.

Mukhija, B. and Khanna, K. (2018) Isolation, characterization and crystal morphology study of Bacillus thuringiensis isolates from soils of Punjab. Journal of Pure and Applied Microbiology, 12, 189-193.

Nair, K., Al-Thani, R., Al-Thani, D., Al-Yafei, F., Ahmed, T. and Jaoua, S. (2018) Diversity of Bacillus thuringiensis strains from Qatar as shown by crystal morphology, $\delta$ endotoxins and cry gene content. Frontiers in Microbiology, 9, 1-10.

Nelder, J.A. and Wedderburn, R.W.M. (1972) Generalized linear models. Journal of the Royal Statistical Society, 135, 370384.

Parra, J.R.P., Alves, G.R., Diniz, A.J.F. and Vieira, J.M. (2016) Tamarixia radiata (Hymenoptera: Eulophidae) $\times$ Diaphorina citri (Hemiptera: Liviidae): mass rearing and potential use of the parasitoid in Brazil. Journal of Integrated Pest Management, 7, 1-11.

Parra, J.R.P., Lopes, J.R.S., Torres, M.L.G., Nava, D.E. and Paiva, P.E.B. (2010) Bioecologia do vetor Diaphorina citri e transmissão de bactérias associadas ao Huanglongbing. Citrus Research Technology, 31, 37-51.

Pelz-Stelinski, K.S., Brlansky, R.H., Ebert, T.A. and Rogers, M.E. (2010) Transmission parameters for Candidatus Liberibacter asiaticus by Asian citrus psyllid (Hemiptera: Psyllidae). Journal of Economic Entomology, 103, 15311541.

Porcar, M., Grenier, A.M., Federici, B. and Rahbé, Y. (2009) Effects of Bacillus thuringiensis $\delta$-endotoxins on the pea aphid (Acyrthosiphon pisum). Applied and Environmental Microbiology, 75, 4897-4900.

Praça, L.B., Caixeta, C.F., Gomes, A.C.M.M. and Monnerat, R.G. (2013) Selection of Brazilian Bacillus thuringiensis strains for controlling diamondback moth on cabbage in a systemic way. Bt Research, 4, 1-7.

Praça, L.B., Gomes, A.C.M.M., Cabral, G., Martins, E.S., Sujii, E.H. and Monnerat, R.G. (2012) Endophytic colonization by Brazilian strains of Bacillus thuringiensis on cabbage seedlings grown in vitro. Bt Research, 3, 11-19.

Qureshi, J.A., Kostyk, B.C. and Stansly, P.A. (2014) Insecticidal suppression of Asian citrus psyllid Diaphorina citri (Hemiptera: Liviidae) vector of huanglongbing pathogens. PLoS ONE, 9, e112331.

Rabinovitch, L., Vivoni, A.M., Machado, V., Knaak, N., Berlitz, D.L., Polanczyk, R.A., et al. (2017) Bacillus thuringiensis characterization: morphology, physiology, biochemistry, pathotype, cellular, and molecular aspects. Bacillus thuringiensis and Lysinibacillus sphaericus, Characterization and Use in the Field of Biocontrol (eds. L. Fiuza, R. Polanczyk \& N. Crickmore), pp. 1-18. Springer, Cham.

R Development Core Team (2018) R: A Language and Environment for Statistical Computing. Vienna, Austria.

Schnepf, E., Crickmore, N., Van Rie, J., Lereclus, D., Baum, J., Feitelson, J., et al. (1998) Bacillus thuringiensis and 
pesticidal crystals proteins. Microbiology and Molecular Biology Reviews, 62, 775-806.

Sétamou, M., Simpson, C.R., Alabi, O.J., Nelson, S.D., Telagamsetty, S. and Jifon, J.L. (2016) Quality matters: influences of citrus flush physicochemical characteristics on population dynamics of the Asian citrus psyllid (Hemiptera: Liviidae). PLoS ONE, 11, e0168997.

Sheikh, A.A., Wani, M.A., Bano, P., Nabi, S.U., Bhat, T.A., Bhat, M.A., et al. (2017) An overview on resistance of insect pests against Bt crops. Journal of Entomology and Zoology Studies, 5, 941-948.

Tanuja, Bisht, S.C. and Mishra, P.K. (2013) Ascending migration of endophytic Bacillus thuringiensis and assessment of benefits to different legumes of N.W. Himalayas. European Journal of Soil Biology, 56, 56-64.

Tao, A., Pang, F., Huang, S., Yu, G., Li, B. and Wang, T. (2014) Characterisation of endophytic Bacillus thuringiensis strains isolated from wheat plants as biocontrol agents against wheat flag smut. Biocontrol Science and Technology, 24, 901-924.

Tiwari, S., Mann, R.S., Rogers, M.E. and Stelinski, L.L. (2011) Insecticide resistance in field populations of Asian citrus psyllid in Florida. Pest Management Science, 67, 1258-1268.

Torres-Quintero, M.C., Arenas-Sosa, I., Hernández-Velázquez, V.M., Suárez-Rodríguez, R. and Peña-Chora, G. (2016) Characterization of Bacillus thuringiensis (Bacillaceae) strains pathogenic to Myzus persicae (Hemiptera: Aphididae). Florida Entomologist, 99, 639-643.

Vidal-Quist, J.C., Rogers, H.J., Mahenthiralingam, E. and Berry, C. (2013) Bacillus thuringiensis colonizes plant roots in a phylogeny-dependent manner. Federation of European Microbiological Societies Microbiology Ecology, 86, 474-489.

Walters, F.S. and English, L.H. (1995) Toxicity of Bacillus thuringiensis $\delta$-endotoxins toward the potato aphid in an artificial diet bioassay. Entomologia Experimentalis et Applicata, 77, 211-216.

Whiteley, H.R. and Schnepf, H.E. (1986) The molecular biology of parasporal crystal body formation in Bacillus thuringiensis. Annual Review of Microbiology, 40, 549-576.
Xu, C., Wang, B.C., Yu, Z. and Sun, M. (2014) Structural insights into Bacillus thuringiensis Cry, Cyt and Parasporin toxins. Toxins, 6, 2732-2770.

Manuscript received October 3, 2018

Final version received November 16, 2018

Accepted November 26, 2018

\section{Supporting Information}

Additional supporting information may be found online in the Supporting Information section at the end of the article.

Fig. S1 Image of phase contrast microscopy showing spores, crystals, and endospore structures present in $\mathrm{Bt}$ suspensions after $3 \mathrm{~d}$ of cultivation: recombinant strain cry $4 B$ exhibiting spherical crystals (A) and strain S1302 showing bipyramidal crystals (B).

Fig. S2 Detection of recombinant Bt strains with each cry/cyt gene. (M) indicates the 100 bp ladder, Invitrogen; $\mathrm{H}_{2} \mathrm{O}$ and $\mathrm{N}$ indicate negative controls from the isolation of young shoots; $c r y 1 A, c r y 1 A b, c r y l A c, c r y 2 A a, c r y 4 A$, cry $4 B, \operatorname{cry} 10, \operatorname{cry} 11, c y t 1 A$, and $c y t 1 B$ represent the genes present in the strains evaluated.

Fig. S3 Morphology of Bt colonies from the isolation of fresh leaves of citrus and dead nymphs. Bt colonies isolated from leaves: (A) control negative, (B) UFC from Cry1 1-treated seedlings, (C) Bt colony enlargement on Cry1 1-treated seedlings, (D) UFC from seedlings treated with S1450, and (E) colony enlargement of Bt on seedlings treated with S1450.

Fig. S4 Assessment of Diaphorina citri nymph survival after feeding on (A) and (B) control, noninoculated "Pera" sweet orange seedlings, (C) and (D) citrus seedlings inoculated with Bt strain S1989 (dead nymphs). 